\title{
Experimental and Modeling Studies of a Four-Trophic Level Predator-Prey System
}

\author{
James M. Graham ${ }^{1}$ and Raymond P. Canale ${ }^{2}$ \\ 'Department of Botany, University of Wisconsin, Madison, Wisconsin 53706; and \\ ${ }^{2}$ Department of Civil Engineering, University of Michigan, Ann Arbor, Michigan 48109
}

\begin{abstract}
Experimental studies of a microbial food chain involving organic carbon substrates, Enterobacter aerogenes, and ciliate protozoans Paramecium primaurelia and Didinium nasutum were conducted in stirred, aerated batch cultures. Quantitative measurements were made of organic carbon levels and of cell numbers, mean cell volumes, and total biovolumes for all three microbial populations. A mathematical model based on Monod kinetics was developed to describe this four-trophic level predator-prey system. The model was formulated in terms of biovolume, which is the product of cell numbers and mean cell size, and includes terms for biovolume decay. Batch culture data were used to derive parameter values, and model simulations were compared to experimental results. Despite the significance of Paramecium-Didinium studies in ecological literature, the entire food chain has not been previously studied or modeled.
\end{abstract}

\section{Introduction}

With the development of continuous culture devices for long-term growth of microorganisms under constant conditions and the mathematical equations to describe microbial growth dynamics, a number of investigators have studied predator-prey systems involving heterotrophic protozoa and various prey organisms [12]. These studies have in common the measurement of all trophic levels, which requires use of electronic counting techniques for assaying microbial populations, and the use of mathematical models based on Monod kinetics, which explicitly define growth of one microorganism in terms of its food resource. One of the earliest such studies of heterotrophic protozoan and bacterial populations in continuous culture was that of Drake et al. [10] who studied predatorprey interactions between the myxamoeba Dictyostelium discoideum and the bacterium Escherichia coli $\mathrm{B} / \mathrm{r}$. Oscillations in predator, prey, and substrate were observed [33]. Other continuous culture studies have examined ciliate protozoa as bacterial predators $[6,9,15]$. In the most complex continuous culture study to date, Jost et al. [19] and Tsuchiya et al. [34] examined the effect of predation by Tetrahymena pyriformis on competition between $E$. coli and Azotobacter vinelandii for glucose substrate. Bader et al. [2] reported on predator-prey interactions between the ciliate Colpoda steini and blue-green 
alga Anacystis nidulans. All of these studies involve only three trophic levels. Studies involving interactions between protozoa have not yet been reported [12].

Interactions between heterotrophic protozoa, however, have been a favorite subject of study among experimental and theoretical ecologists because they exhibit a range of population interactions similar to metazoans and can therefore serve as models of general biological systems [13, 17, 20, 23-25]. Because heterotrophic protozoa reach large population sizes in small volumes and possess rapid growth rates, they are convenient for testing mathematical models of population phenomena, such as competition and predation. Gause [13] was one of the first experimental ecologists to use heterotrophic protozoa as general biological systems to test mathematical models of various population phenomena. In one series of classical experiments, Gause selected a microbial predatorprey system, which consisted of the bacterial grazer Paramecium caudatum and its predator Didinium nasutum, and tried to determine what factors led to coexistence or extinction in predator-prey systems. On the basis of these experiments, Gause concluded that in a homogeneous environment the predator-prey relation was unstable and led to self-annihilation. More recently, Luckinbill $[21,22]$ showed that the outcome of the Paramecium-Didinium interaction in a homogeneous system could be altered by varying the level of dissolved organic carbon provided to the bacteria. Experimental ecologists, however, have not quantified the levels of dissolved organic carbon or bacteria $[13,21,22,25]$. When mathematical models have been applied by experimental ecologists to protozoan systems, the models have been of the logistic and LotkaVolterra type rather than a Monod-type model. Salt [30] pointed out that Gause's work has had a very strong influence on ecological concepts about predation. Clearly, a more dynamic approach to the Paramecium-Didinium system in which all trophic levels are measured and modeled would be appropriate.

In the present paper, the growth and interactions in a four-trophic level system consisting of organic carbon substrates, the bacterium Enterobacter aerogenes, grazing ciliate Paramecium primaurelia and predatory ciliate Didinium nasutum are studied in batch cultures. Electronic counting and sizing techniques are examined for all three microbial populations in mixed cultures. A mathematical model based on Monod kinetics is developed, optimal constants are derived from batch culture experiments, and the model is used to simulate the system. These results are an essential first step toward study of the entire system in continuous culture and testing of theories on predation phenomena.

\section{Materials and Methods}

\section{Microorganisms}

Enterobacter aerogenes (ATCC 13048) was selected as a suitable food organism and was maintained aerobically on trypticase soy agar plates. Paramecium primaurelia (stock 540 ) was obtained in axenic culture from the laboratory of Dr. S. L. Allen, Division of Biological Sciences, University of Michigan. Stock cultures of $P$. primaurelia were grown on $E$. aerogenes in $5 \mathrm{ml}$ of culture 
medium. Didinium nasutum (ATCC 30399) was maintained in cultures of $P$. primaurelia and transferred to fresh cultures every other day. The general procedures used for sterilization of Didinium have been described previously [1].

\section{Culture Medium and Methods}

The culture medium contained in g/liter: $\mathrm{Na}_{2} \mathrm{HPO}_{4} \cdot 7 \mathrm{H}_{2} \mathrm{O}, 1.34 ; \mathrm{KH}_{2} \mathrm{PO}_{4}, 0.68 ; \mathrm{NaOH}, 0.08 ; \mathrm{KCl}$, $0.037 ; \mathrm{NaCl}, 0.117 ; \mathrm{MgSO}_{4} \cdot 7 \mathrm{H}_{2} \mathrm{O}, 0.123 ; \mathrm{CaCl}_{2} \cdot 2 \mathrm{H}_{2} \mathrm{O}, 0.014 ; \mathrm{MnCl}_{2} \cdot 4 \mathrm{H}_{2} \mathrm{O}, 0.002 ; \mathrm{NH}_{4} \mathrm{Cl}, 0.191$; Cerophyl, a brand name for dehydrated cereal grass (Cerophyl Corp., Kansas City, Missouri), 2.50. The pH of the medium was about 7.2. Before autoclaving, the medium was mixed, boiled for five min, and filtered through $18.5 \mathrm{~cm}$ rapid filter paper (Scientific Products) and twice through prewashed Type A-E $47 \mathrm{~mm}$ glass fiber filters (Gelman Corp.) to remove particles likely to interfere with electronic counting of bacterial cells. A few sprays of antifoam A (Dow Corning) were added to reduce foaming. Sterile culture medium would not support growth of axenic $P$. primaurelia.

Batch culture experiments were conducted at $20^{\circ} \pm 1^{\circ} \mathrm{C}$ in a constant temperature chamber. The batch culture vessels were assembled from two-liter flat-bottomed pyrex boiling flasks equipped with ports for inoculation, sample removal, aeration with humidified sterile air, and air exhaust. The working volume in all batch culture experiments was $1.5 \mathrm{~L}$. Air flow was maintained at 1 $\mathrm{L} / \mathrm{min}$. A magnetic stir bar provided continuous mixing. Culture samples were removed with sterile $25 \mathrm{ml}$ syringes and checked for contaminating microorganisms by streaking and incubating trypticase soy agar plates for two days at $37^{\circ} \mathrm{C}$.

\section{Analytical Techniques}

Organic Carbon Analysis. Samples for carbon analysis $(9-10 \mathrm{ml})$ were filtered through prewashed $0.45 \mu \mathrm{m}$ filters into sterile test tubes containing two drops of $1: 4 \mathrm{H}_{2} \mathrm{SO}_{4}$ and stored at $2-3^{\circ} \mathrm{C}$ until analyzed on a Beckman Model 915 total organic carbon analyzer. At least four replicates were run for each sample and carbon standard analyzed. Growth of $E$. aerogenes in the culture medium left about $54 \%$ refractory organic carbon in solution; this refractory carbon was subtracted from total carbon to give an estimate of utilizable organic carbon present during experiments.

Bacterial Population Analysis. Electronic estimates of cell concentration, mean cell volume, and biovolume of $E$. aerogenes were obtained with a Coulter Model ZB equipped with a $30 \mu \mathrm{m}$ aperture tube and connected to a Model P-64 size distribution analyzer, which was calibrated with 1.305 $\mu \mathrm{m}$ polystyrene spheres (Coulter Electronics). Preliminary experiments indicated that an amplification switch setting of one-half and aperture current of one-quarter were optimal. Culture samples were diluted with $0.45 \mu \mathrm{m}$ filtered $0.9 \% \mathrm{NaCl}$ to give cell counts from 5,000 to $50,000 / 0.05 \mathrm{ml}$. For each sample, six to eight replicate counts and three size distributions were obtained. Electronic counts were compared with viable counts on trypticase soy agar plates. Matched weight filters 447 $\mathrm{mm}, 0.45 \mu \mathrm{m}$ filters which are matched to $\pm 0.1 \mathrm{mg}$, Millipore Corp.) were used to determine bacterial dry weights (biomasses) for comparison with electronic biovolume estimates.

Paramecium Population Analysis. Electronic estimates of cell concentration, mean cell volume, and biovolume of $P$. primaurelia were obtained with a Coulter Model B equipped with a $560 \mu \mathrm{m}$ aperture tube and connected to a Model P-64 size distribution analyzer and X-Y recorder. Calibration for $P$. primaurelia volume analysis required $40 \mu \mathrm{m}$ and $50 \mu \mathrm{m}$ polystyrene spheres (Duke Standards). An amplification switch setting of two and aperture current of two or one were optimal for P. primaurelia. Culture samples of $25 \mathrm{ml}$ or $50 \mathrm{ml}$ were diluted in $0.225 \% \mathrm{NaCl}$ to a total volume of $225 \mathrm{ml}$, which gave cell counts of $10-600 / 2 \mathrm{ml}$. In $0.9 \% \mathrm{NaCl}$, P. primaurelia became 
swollen, causing size distributions to shift, and eventually burst. In the empirically derived $0.225 \%$ $\mathrm{NaCl}$, however, the protozoa remained active, size distributions were stable, and the protozoa grew when provided with bacteria. For each sample, five replicate protozoan counts and two size distributions were measured. A computer program was used to integrate the graphs of cell size distribution to derive values for mean cell size and biovolume. Electronic estimates of cell numbers were compared with optical counts, which were obtained by counting all $P$. primaurelia in five replicate $1 \mathrm{ml}$ subsamples as they were drawn into a micropipette. To obtain optical measurements of cell volume for comparison with electronic estimates, 50 or more $P$. primaurelia were transferred to a drop of $5 \% \mathrm{NiSO}_{4}$ on a microscope slide. The length and width of the first 25 cells were then measured at $200 \times$ and their volumes computed based on the formula for an ellipsoid.

Didinium Population Analysis. Electronic estimates of $D$. nasutum numbers, mean cell sizes, and biovolumes were made on the same Coulter counter equipment as $P$. primaurelia. Calibration for D. nasutum volume analysis required $80 \mu \mathrm{m}$ polystyrene spheres (Duke Standards). For D. nasutum, an amplification switch setting of four and aperture current of four or two were used. The predators were counted at the same dilution in $0.225 \% \mathrm{NaCl}$ as were their prey. When both protozoa were present in culture samples, the sample volume permitted only five $D$. nasutum cell counts and one size distribution to be recorded after counts and size distributions of $P$. primaurelia had been collected. After $P$. primaurelia became extinct, however, two size distributions of Didinium were made. At Coulter settings of amplification four and aperture current four or two, only Didinium were counted, but at settings used for $P$. primaurelia, both protozoa were counted. The number of $P$. primaurelia was determined by subtracting the count of Didinium from the total count. Didinium were, however, too large to be included in Paramecium cell size distributions. A computer program was also used to integrate cell size distributions. Optical counts of $D$. nasutum were made by micropipette as with $P$. primaurelia. Optical measurements of predator cell volume were made by expelling 40 to $50 \mathrm{D}$. nasutum into a drop of Bouin's solution. The length and width of the first $25 \mathrm{D}$. nasutum were measured and volumes computed with the formula for an ellipsoid.

\section{Mathematical Model}

The mathematical model presented in this section is based on simple material balance and saturation kinetics to describe growth as a function of resource utilization. Monod [27, 28] developed a series of equations to describe saturation of a bacterial population specifically in terms of utilization of some essential substrate. A detailed theoretical development and experimental testing of Monod's equations has been presented by Herbert et al. [16], and therefore only a brief summary of Monod's equations is presented here. When all essential substrates are present in excess, bacterial growth in batch culture can be described by the familiar exponential equation

$$
\frac{1}{\mathrm{~B}} \frac{\mathrm{dB}}{\mathrm{dt}}=\mu
$$

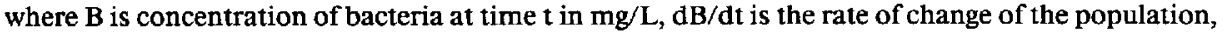
and $\mu$, the rate of increase per unit organism concentration, is the specific growth rate in $\mathrm{h}^{-1}$. Monod [27] first showed that the relationship between the specific growth rate and the substrate concentration could be described by

$$
\mu=\mu_{\max } \frac{\mathrm{S}}{\mathrm{K}_{\mathrm{s}}+\mathrm{S}}
$$

where $\mathrm{S}$ is substrate concentration in $\mathrm{mg} / \mathrm{L}, \mu_{\max }$ the maximum growth rate constant in $\mathrm{h}^{-1}$, and $\mathrm{K}_{s}$ the saturation constant in $\mathrm{mg} / \mathrm{L}$, which is that substrate concentration at which $\mu=1 / 2 \mu_{\max }$. The form of equation 2 is hyperbolic with $\mu$ being proportional to $S$ at low concentrations but approaching a limit of $\mu_{\max }$ at high concentrations. Hyperbolic functions occur commonly in predator-prey 
models [26]. Finally, Monod [28] also showed that bacterial growth rate was a constant fraction of the substrate utilization rate

$$
\frac{\mathrm{dB}}{\mathrm{dt}}=-\mathrm{Y} \frac{\mathrm{dS}}{\mathrm{dt}}
$$

where $\mathrm{Y}$ is a dimensionless yield constant which relates substrate utilization tó bacterial growth. Equations one to three can be combined to give a quantitative description of bacterial growth and substrate utilization in batch culture and, with minor changes, in continuous culture.

Mathematical equations similar to those in equations one to three were subsequently used to describe growth of ciliate protozoa on bacterial prey in both batch and continuous culture. Proper and Garver [29] first showed that the specific growth rate of the ciliate Colpoda steini on Escherichia coli could be described by an expression identical to equation two. At low bacterial concentrations, protozoan growth is limited by frequency of encountering bacteria but at high bacterial concentration growth can be limited by rate of ingestion or digestion. The mathematical model for changes in substrate, bacteria, and protozoa in batch and continuous culture has been described previously $[6,9,10]$ and subjected to detailed analysis of the behavior of its solutions $[5,18,33]$. In experimental studies, this model has been used extensively to describe three trophic level systems involving the ciliate Tetrahymena pyriformis feeding on bacteria $[6,9,19]$, the myxamoeba Dictyostelitum discoideum on $E$. coli $[10,33]$, and the ciliate Colpoda steini on the blue-green alga Anacystis nidulans [2].

The mathematical model for a four trophic level system involving Paramecium and Didinium was obtained by adding an equation for the second predator to the previously described three trophic level model. As in equation two, the specific growth rate of Didinitum was described as a hyperbolic function of Paramecium concentration. Experiments by Salt [30] and Hewett [17] support such a formulation for Didinium. The equations for the four trophic level predator-prey system in batch culture are

$$
\begin{aligned}
\frac{\mathrm{dS}}{\mathrm{dt}} & =-\frac{\mu_{\max }}{\mathrm{Y}} \frac{\mathrm{S}}{\mathrm{K}_{\mathrm{s}}+\mathrm{S}} \mathrm{B} \\
\frac{\mathrm{dB}}{\mathrm{dt}} & =\mu_{\max } \frac{\mathrm{S}}{\mathrm{K}_{\mathrm{s}}+\mathrm{S}} \mathrm{B}-\mathrm{d}_{\mathrm{b}} \mathrm{B}-\frac{\eta_{\max }}{\mathrm{W}} \frac{\mathrm{B}}{\mathrm{K}_{\mathrm{b}}+\mathrm{B}} \mathrm{G} \\
\frac{\mathrm{dG}}{\mathrm{dt}} & =\eta_{\max } \frac{\mathrm{B}}{\mathrm{K}_{\mathrm{b}}+\mathrm{B}} \mathrm{G}-\mathrm{d}_{\mathrm{g}} \mathrm{G}-\frac{\sigma_{\max }}{\mathrm{Z}} \frac{\mathrm{G}}{\mathrm{K}_{\mathrm{g}}+\mathrm{G}} \mathrm{P} \\
\frac{\mathrm{dP}}{\mathrm{dt}} & =\sigma_{\max } \frac{\mathrm{G}}{\mathrm{K}_{\mathrm{g}}+\mathrm{G}} \mathrm{P}-\mathrm{d}_{\mathrm{p}} \mathrm{P}
\end{aligned}
$$

$\mathrm{S}$ is the concentration of utilizable organic carbon substrates in the culture vessel in $\mathrm{mg} / \mathrm{L}$. B, H, and $P$ are the concentrations of $E$. aerogenes, $P$. primaurelia, and $D$. nasutum, respectively, in $\mu \mathrm{m}^{3} / \mathrm{mL}$, and $\mu_{\max }, \eta_{\max }$, and $\sigma_{\max }$ are the corresponding maximum specific growth rates in $\mathrm{h}^{-1} . \mathrm{Y}$, $W$, and $Z$ are yield constants and $K_{s}, K_{b}$, and $K_{g}$ saturation constants. $Y$ is expressed in $\mu \mathrm{m}^{3} / \mathrm{mg}$, and $W$ and $Z$ are dimensionless. $K_{s}$ is in $m g / L$, and $K_{b}$ and $K_{g}$ are expressed in $\mu m^{3} / m L$. The terms $d_{b}, d_{g}$, and $d_{p}$ are biovolume decay constants expressed in $h^{-1}$.

Monod [27] originally considered dry weight to be the appropriate measure of bacterial concentration, but with the exception of Canale et al. [6] and Canale and Cheng [7], who used biovolume as the concentration unit of the ciliate predator, most batch and continuous culture studies have used cell numbers. It is not appropriate to use cell numbers as a measure of concentration in equations 4-7 because cell numbers may represent different biomasses if cell sizes are variable. Therefore, the four trophic level model was formulated in terms of biovolume, which is the product of cell numbers and mean cell size. Because biovolume declines due to both cell lysis and reduction in cell volume when food resources are depleted, first-order biovolume decay terms were included in the model $[6,7]$. Incorporation of these decay terms is equivalent to assuming a maintenance metabolism for the organisms. When food resources are depleted, metabolism proceeds at the expense of accumulated biovolume. 

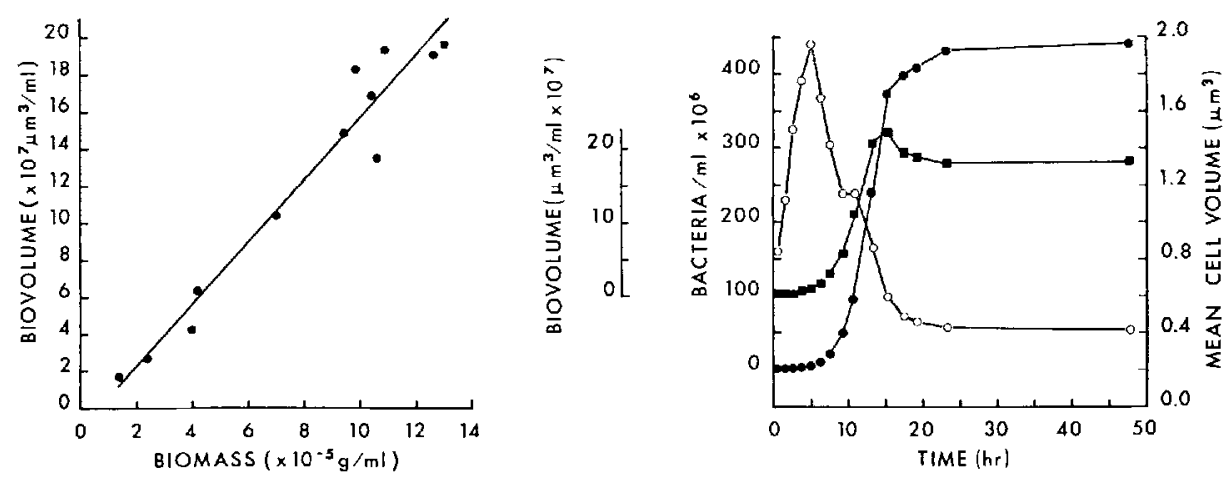

Fig. 1. Linear relationship between bacterial biovolume estimates and the corresponding determinations of bacterial biomass (dry weight).

Fig. 2. Changes in cell numbers, mean cell volume, and biovolume during batch culture growth of Enterobacter aerogenes. ( $)$ cell numbers, $(\mathrm{O})$ mean cell volume, $(\square)$ biovolume.

\section{Results}

The growth and decline of each microbial population was examined in batch cultures to determine patterns of changes in cell numbers, mean cell volumes, and biovolumes and to correlate measurements of these parameters made by electronic particle counters and size distribution analyzers with measurements made by more conventional methods. Total electronic counts of $E$. aerogenes exceeded plate counts during lag and stationary phases when intact but nonviable bacterial cells were present. During exponential phase, the correspondence was quite close. The total number of particles is probably a better indication of available protozoan food than viable cells alone. Comparison between electronic counts and plate counts of bacterial cell numbers indicated that the presence of the protoza did not adversely affect the accuracy of the electronic estimates (Tables 1 and 2 ). In Table $1, P$. primaurelia reduced its prey to an average concentration of $3.2 \times 10^{5}$ viable cells $/ \mathrm{ml}$. The data in Table 2 were obtained during the experiments shown in Fig. 9, but the data in Table 1 were from an experiment separate from those in Fig. 8. The linear regression for electronically determined bacterial biovolume vs biomass, determined by measurement of dry weight (Fig. 1), was highly significant $(P<0.001)$. Changes in cell numbers, mean cell sizes, and biovolumes of $E$. aerogenes during batch culture growth are shown in Figure 2. Bacterial numbers remained constant during lag phase, but average cell size increased rapidly and reached a maximum shortly after the culture entered exponential phase. Mean cell size declined during exponential phase and reached a constant minimum size of $0.42 \mu \mathrm{m}^{3}$ in stationary phase. Maximum biovolume did not correspond to maximum cell numbers but occurred at about $15 \mathrm{~h}$ when mean cell volume was still greater than minimum cell size.

Electronic and optical estimates of cell numbers and mean cell volumes of the grazing ciliate $P$. primaurelia each closely corresponded, and consequently biovolume estimates were highly correlated (Fig. 3). The pattern of changes in cell numbers, mean cell volumes, and biovolumes of $P$. primaurelia during 
Table 1. Comparison between electronic counts and plate counts of Enterobacter aerogenes in a stirred, aerated batch reactor with Paramecium primaurelia.

\begin{tabular}{|c|c|c|}
\hline Time (h) & $\begin{array}{c}\text { Coulter } \\
\text { counts }{ }^{a} \times 10^{6} \\
\text { cells } / \mathrm{ml}\end{array}$ & $\begin{array}{c}\text { Plate } \\
\text { counts }{ }^{t} \times 10^{6} \\
\text { cells } / \mathrm{ml}\end{array}$ \\
\hline 49.67 & 706.18 & 600 \\
\hline 73.14 & 642.25 & 437 \\
\hline 97.08 & 491.00 & 380 \\
\hline 122.47 & 119.70 & 70.7 \\
\hline 145.67 & 3.013 & 0.190 \\
\hline 169.92 & 0.850 & 0.156 \\
\hline 193.25 & 1.170 & 0.297 \\
\hline 218.67 & 0.387 & 0.223 \\
\hline 239.17 & 0.346 & 0.226 \\
\hline 263.58 & 0.119 & 0.264 \\
\hline 288.58 & 0.326 & 0.345 \\
\hline 311.95 & 0.488 & 0.527 \\
\hline 336.41 & 0.600 & 0.660 \\
\hline
\end{tabular}

a Based on 6-8 replicate counts

${ }^{h}$ Based on 3 replicate platings

Table 2. Comparison between electronic counts and plate counts of Enterobacter aerogenes in a stirred, aerated batch reactor with Paramecium primaurelia and Didinium nasutum.

\begin{tabular}{|c|c|c|}
\hline Time (h) & $\begin{array}{l}\text { Coulter } \\
\text { counts }^{a} \times 10^{6} \\
\text { cells } / \mathrm{ml}\end{array}$ & $\begin{array}{c}\text { Plate } \\
\text { counts }{ }^{b} \times 10^{6} \\
\text { cells } / \mathrm{ml}\end{array}$ \\
\hline 48.10 & 693.05 & 520 \\
\hline 69.30 & 455.67 & 340 \\
\hline 91.92 & 4.23 & 0.6 \\
\hline 140.77 & 28.60 & 24.5 \\
\hline 168.77 & 33.99 & 23.0 \\
\hline 187.21 & 29.04 & 16.0 \\
\hline
\end{tabular}

${ }^{a}$ Based on 6-8 replicate counts

"Based on 3 replicate platings

batch culture growth is shown in Figure 4. Again mean cell volume initially increased and reached a maximum as the population entered exponential phase. Mean cell size then declined rapidly during exponential phase and continued to decline slowly during the remainder of the experiment. Cell numbers also showed a slow decline from the maximum level. Maximum Paramecium biovolume occurred about $70 \mathrm{~h}$ after inoculation of the batch culture with protozoa, but cell numbers did not reach the maximum level until more than $90 \mathrm{~h}$ had elapsed (Fig. 4). Biovolume decline was the product of declining cell numbers and mean cell volume.

The correspondence between electronic and optical measurements of cell 

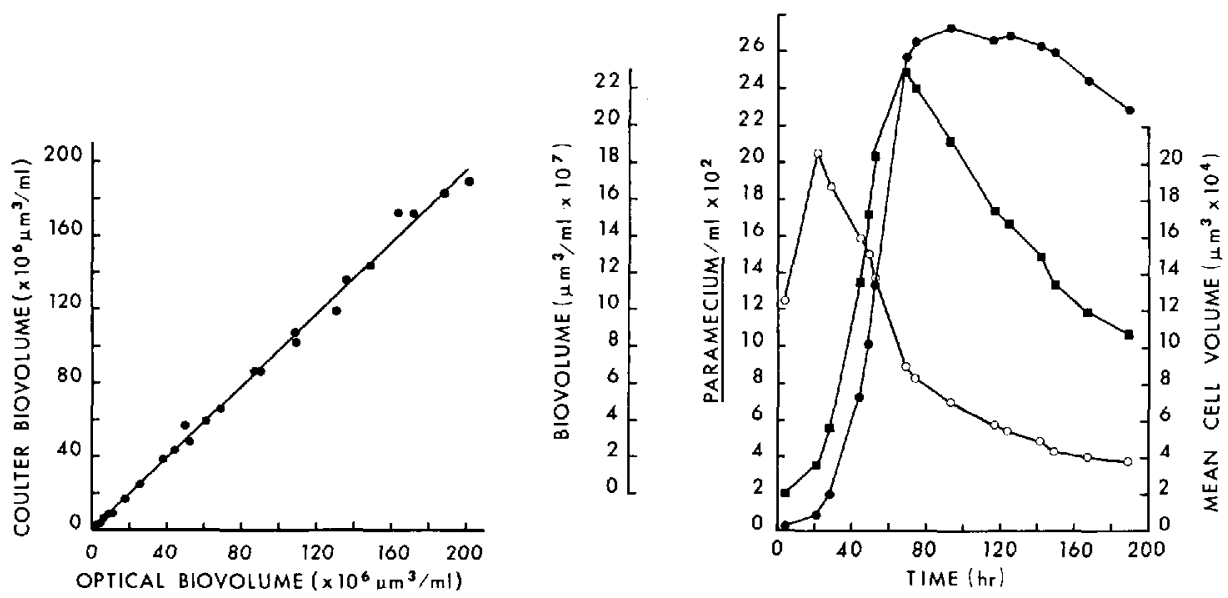

Fig. 3. Linear relation between electronic biovolume estimates and optically measured biovolumes of Paramecium primaurelia.

Fig. 4. Changes in cell numbers, mean cell volume, and biovolume during batch culture growth of Paramecium primaurelia. (๑) cell numbers, $(O)$ mean cell volume, $(\square)$ biovolume.
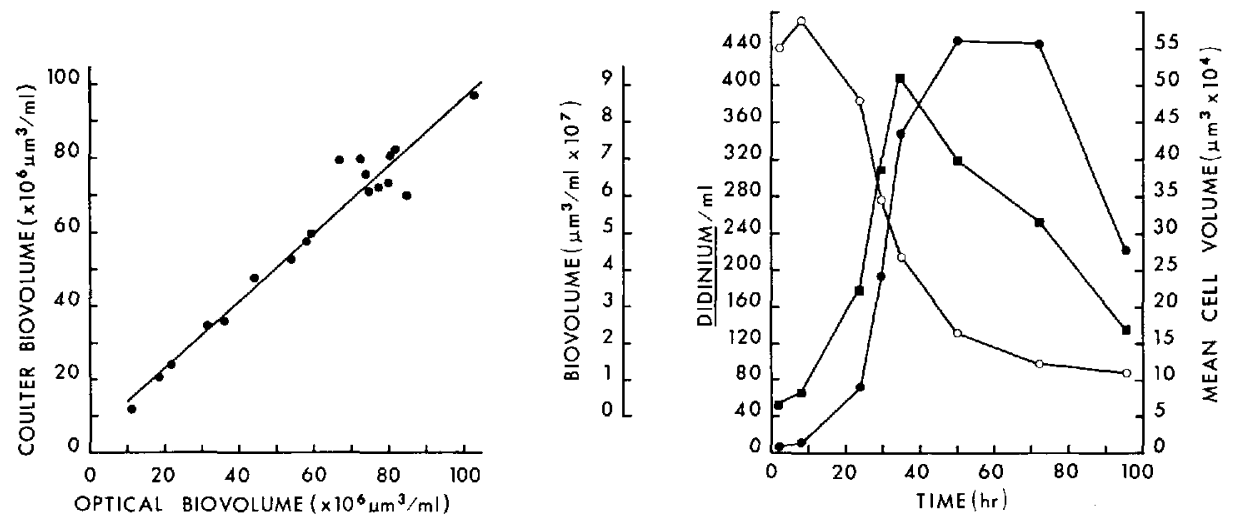

Fig. 5. Linear relation between electronic biovolume estimates and optically measured biovolumes of Didinium nasutum.

Fig. 6. Changes in cell numbers, mean cell volume, and biovolume of Didinium nasutum during batch culture growth. (O) cell numbers, $(O)$ mean cell volume, $(\square)$ biovolume.

numbers and mean cell volumes of the predatory ciliate Didinium nasutum also proved quite satisfactory, although initial counts were somewhat scattered because they were based on very small numbers of cells. The resulting biovolume estimates were highly correlated (Fig. 5). Changes in cell numbers, mean ccll volumes, and biovolumes of $D$. nasutum during growth in batch culture are shown in Figure 6. The initial increase in mean cell volume was slight, presumably because the predators were near their maximum cell size in the inoculum. Mean cell size declined rapidly as the predators grew exponentially, 

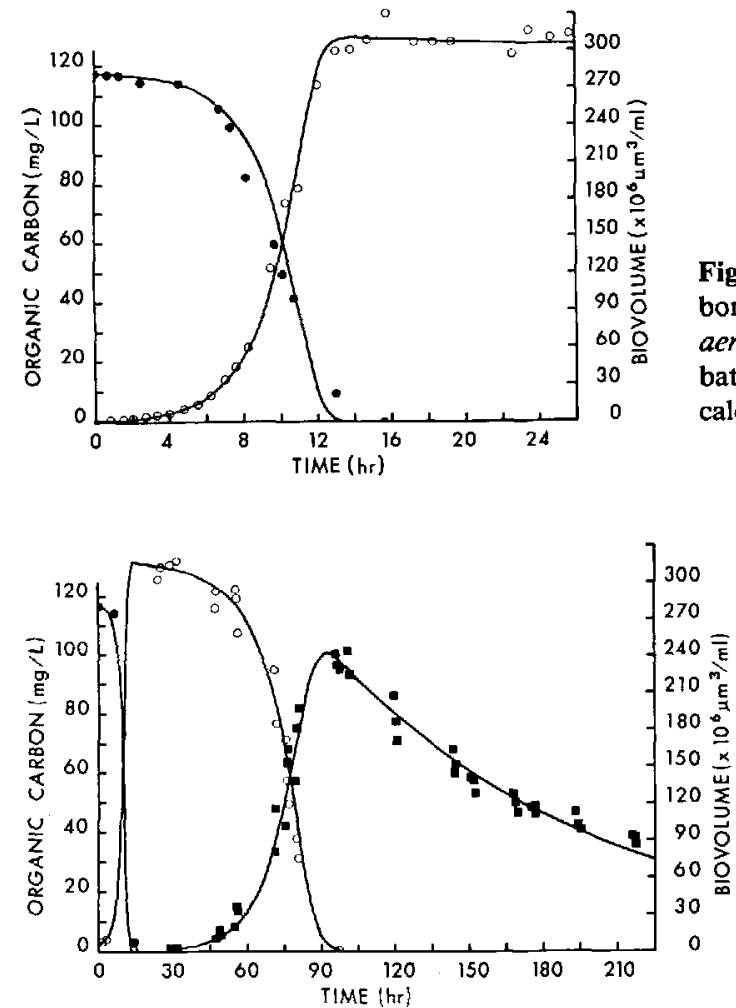

Fig. 7. Removal of utilizable organic carbon ( $\bullet$ and production of Enterobacter aerogenes biovolume $(O)$ in three replicate batch cultures. The curves are fitted model calculations.
Fig. 8. Removal of organic carbon (๑) and changes in biovolume of Enterobacter aerogenes $(O)$ and Paramecium primaurelia $(\square)$ in three replicate batch cultures. All curves are fitted model calculations. Cell numbers for one of the replicates shown in this Figure are included also in Figure 4.

and cell numbers also dropped sharply after $80 \mathrm{~h}$. Maximum Didinium biovolume occurred at about $35 \mathrm{~h}$ when the number of predators $(347 / \mathrm{ml})$ was below the maximum number $(450 / \mathrm{ml})$ reached at $50 \mathrm{~h}$. The predators therefore continued to divide at the expense of their mean cell volume.

After the electronic techniques for counting and sizing the microbial populations were verified, a series of replicated batch culture experiments were conducted. The interaction between dissolved organic carbon substrates and Enterobacter was first examined, then grazing on bacteria by $P$. primaurelia, and finally predation on Paramecium by Didinium nasutum. From these replicated batch experiments the values of growth constants, expressed in terms of biovolume, were derived for use in the mathematical model represented by equations 4-7. Batch culture interactions were simulated by the model and compared to the observed data.

Three replicate stirred, aerated batch cultures were run simultaneously starting with the same initial organic carbon substrate concentration and inoculum of Enterobacter aerogenes. The standard bacterial inoculum used in all batch culture experiments was $25 \mathrm{ml}$ of 24 -h old loop-inoculated medium. The initial bacterial cell concentration averaged about $2.4 \times 10^{6} \mathrm{cells} / \mathrm{ml}$, and the initial mean cell size was about $0.6 \mu \mathrm{m}^{3}$. Organic carbon and bacterial biovolume were followed for more than $300 \mathrm{~h}$. The results were so similar that the data were pooled for graphing and analysis. During the first 12 hours of the exper- 
Table 3. Optimized growth parameters for Monod model with biovolume decay constants.

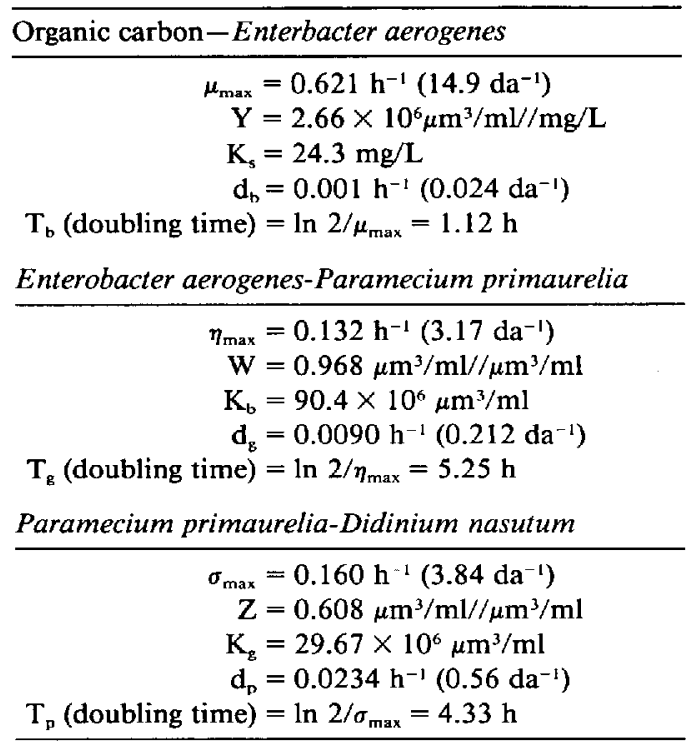

iment, organic carbon was depleted and the maximum bacterial biovolume was produced (Fig. 7). During the remainder of the experiment, bacteral biovolume declined slowly due to cell lysis. Optimal values of growth constants were determined by a computer program which minimized the sum of squared deviations between observed data and model predictions (Table 3 ). The curves in Figure 7 were produced by numerical integration of equations 4 and 5 , without the term for Paramecium grazing.

Three replicate batch cultures were then monitored for 225 hours for organic carbon, bacteria, and $P$. primaurelia. Each batch culture received $15 \mathrm{ml}$ of $72-$ h old $P$. primaurelia culture $27 \mathrm{~h}$ after inoculation with bacteria. The initial concentration of $P$. primaurelia averaged about $16 \mathrm{cells} / \mathrm{ml}$ with a mean cell size of about $146,000 \mu \mathrm{m}^{3}$. The resulting data were again grouped for analysis (Fig. 8). After $100 \mathrm{~h}$, the bacterial population remained at $0.1-1.6 \times 10^{6} \mu \mathrm{m}^{3} /$ $\mathrm{ml}$ as biovolume of Paramecium steadily declined due to the combined effects of declining cell numbers and mean cell size. Optimal parameter values were calculated by computer program (Table 3), and the smooth curves in Figure 8 were obtained by numerical integration of equations 4,5 , and 6 , without the term for Didinium predation.

A final three replicate batch cultures were followed for $195 \mathrm{~h}$, and changes in all four trophic levels were measured. Each batch culture received $20 \mathrm{ml}$ of 48-h old Paramecium culture $24 \mathrm{~h}$ after bacterial inoculation. The Paramecium inoculum resulted in an initial concentration of about $14 \mathrm{cells} / \mathrm{ml}$ with a mean cell size of about $159,000 \mu \mathrm{m}^{3}$. After Paramecium reached maximum biovolume, $20 \mathrm{ml}$ of 48 -h old cultures of Didinium nasutum were added to each batch culture at 92.5 hours. The initial concentration of Didinium was about 


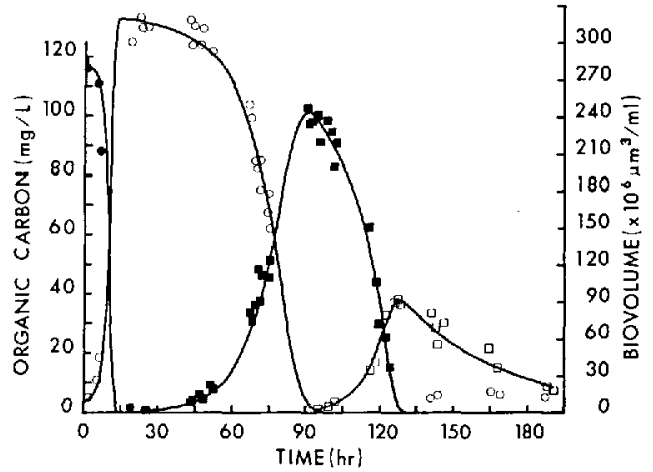

Fig. 9. Removal of organic carbon (O) and changes in biovolume of Enterobacter aerogenes (O), Paramecium primaurelia ( $\square$ ), and Didinium nasutum $(\square)$ in three replicate batch cultures. All curves are fitted model calculations. Cell numbers for one of the replicates shown in this Figure are included also in Figure 6.

7 cells $/ \mathrm{ml}$ with a mean cell size of $607,000 \mu \mathrm{m}^{3}$. The resulting data were again pooled for analysis (Fig. 9) . Up to $90 \mathrm{~h}$, the pattern of changes in Enterobacter and Paramecium were virtually identical to that in Figure 8. After inoculation, Didinium rapidly consumed all their prey and then declined. A secondary regrowth of bacteria occurred after Paramecium were eliminated. Didinium did not appear to eat bacteria, since in these cultures the number of bacteria increased in the presence of Didinium after Paramecium were eliminated. Apparently, as Didinium removed Paramecium, a certain amount of organic carbon substrate was released for bacterial growth. The amount of recycled organic carbon could be estimated at $6.4 \mathrm{mg} / \mathrm{L}$, about $6 \%$ of initial levels, because the coefficient for conversion of organic carbon to bacterial biovolume and the level of secondary bacterial biovolume produced $\left(17.0 \times 10^{6} \mu \mathrm{m}^{3} / \mathrm{ml}\right)$ were known. Plate counts indicated that this regrowth represented viable bacteria and not just a buildup of debris (Table 2). Optimal parameters for Didinium growth were determined by computer program (Table 3 ), and the fitted curves in Figure 9 were obtained by numerical integration of equations 4-7.

\section{Discussion}

The microbial predator-prey system represented by Paramecium and Didinium has long been a favorite subject for study by many investigators $[13,17,21-$ $23,25]$, and it has had a major influence on general theories of predation [12, 30]. Despite this interest in the system, no one previously has attempted to measure or to model all four trophic levels involved simultaneously. Before the development of electronic techniques for counting and sizing mixed cultures of microorganisms, the labor involved in measuring organic carbon substrate levels and cell numbers, mean cell sizes, and biovolumes of three microbial populations simultaneously would have made any quantitative investigation of the entire Paramecium-Didinium system exceedingly difficult. In the present report, electronic estimates of bacterial biovolume were found to be highly corrclated with bacterial biomass (Fig. 1). A number of authors have shown similar high correlations between biovolume and biomass for the algae Euglena [8], Selenastrum and Chlorella [37], and protozoa Tetrahymena $[4,32]$ and Colpidium [31]. Drake and Tsuchiya [11] established the accuracy of electronic 
techniques for counting mixed populations of microorganisms and applied their procedures to differential counting of mixed cultures of bacteria and protozoa, bacteria and yeast, and large and small bacteria. In the present report, it was found possible to count and size two distinct populations of protozoa in mixed culture. Electronic estimates of protozoan biovolumes were highly correlated with optical measurements of biovolume (Figs. 3 and 5). Differential counting and sizing were possible because the cell size distributions of Paramecium and Didinium did not overlap appreciably. When batch cultures were inoculated with Didinium, the mean cell size of $P$. primaurelia was about $60,000 \mu \mathrm{m}^{3}$ or less, but the mean cell size of Didinium ranged from 440,000 to $830,000 \mu \mathrm{m}^{3}$. Thus, the predators were 6-13 times larger than their prey when experiments began. The nearly spherical Didinium were also found to have a narrow, symmetrical cell size distribution which was more uniform than some commercial calibration spheres. Didinium cells became as small as the largest Paramecium only long after all prey had been eaten. Optical methods were preferable only when Didinium numbers were very low at the beginning of batch culture growth.

Biovolume was selected as the unit of population measurement because cell numbers may represent different biomasses when cell sizes are variable. Mean cell volumes varied from $0.4 \mu \mathrm{m}^{3}$ to about $2 \mu \mathrm{m}^{3}$ for Enterobacter aerogenes, from 38,000 $\mu \mathrm{m}^{3}-210,000 \mu \mathrm{m}^{3}$ for Paramecium primaurelia and from 110,000 $\mu \mathrm{m}^{3}-580,000 \mu \mathrm{m}^{3}$ for Didinium nasutum (Figs. 2, 4, and 6). Mean cell size was therefore quite variable in all three microbial populations. The use of biovolume as a measurement of microorganism concentration incorporated this variation into the mathematical model. Maximum biovolume of the resourceutilizing organisms occurred just as that resource was depleted in all three trophic interactions (Figs. 2, 4, and 6). This close coupling between resource consumption and biovolume production did not occur between resource consumption and cell numbers. During lag phase of batch culture growth, cell numbers did not change but mean cell volumes increased (Figs. 2, 4, and 6). Maximum cell numbers occurred after maximum biovolume had been reached and resources were depleted. Thus, the microorganisms continued to divide at the expense of accumulated biovolume, a process Gause [13] described for Didinium as producing an increase in the effective "seizing surface." The use of biovolume in the mathematical model avoided the complications this behavior would entail.

The optimal values of all the growth constants in the mathematical model are given in Table 3. The maximum specific growth rate of Didinium $\left(\sigma_{\max }\right)$ is somewhat larger than that of Paramecium $\left(\eta_{\mathrm{max}}\right)$, a finding consistent with other reports $[13,21]$. The yield coefficients represent gross yields rather than net yields because biovolume decay is included in the model. Because the halfsaturation constant for Paramecium grazing on bacteria $\left(K_{b}\right)$ was larger than that for Didinium capturing its prey $\left(\mathrm{K}_{\mathrm{g}}\right)$, Paramecium were evidently less effective at picking up prey at low concentrations than were Didinium. At least in part, this difference in effectiveness may be due to the great difference in the sizes of prey. Enterobacter cells average around $0.4 \mu \mathrm{m}^{3}$ at stationary phase while Paramecium cells range from $38,000 \mu \mathrm{m}^{3}-$ over $200,000 \mu \mathrm{m}^{3}$. The biovolume decay coefficient for bacteria $\left(\mathrm{d}_{\mathrm{b}}\right)$ was only about $2 \%$ per day compared 
with $21 \%$ per day for $P$. primaurelia and $56 \%$ per day for $D$. nasutum. Didinium perhaps expends considerably more energy in pursuit of prey than does Paramecium.

The mathematical model presented in this paper shows a reasonable fit to the measured results at high population concentrations. The addition of biovolume decay terms to the basic Monod formulation was essential, particularly for the protozoans which have high rates of biovolume loss. The decline in biovolume after the maximum level was reached was due to the combined effects of fewer cells and smaller average cell sizes. The importance of these biovolume decay terms in the equations for Paramecium and Didinium growth is evident in Figures 8 and 9. Without a decay term to represent maintenance metabolism, the predicted Paramecium and Didinium biovolumes would remain at a constant maximum level.

The Monod model predicts that Paramecium biovolume should decline continuously to levels below that which would indicate even one cell in the entire batch culture. $P$. primaurelia is actually eliminated entirely, reflecting the fact that protozoan biovolume comes in large discrete units. The Monod model also predicts that Paramecium should reduce the population of its bacterial prey to very low densities. Bacterial population levels actually remain steady at $0.2-1.5 \times 10^{6} \mathrm{cells} / \mathrm{ml}$ in batch cultures with Paramecium only. Plate counts indicate that these persistent high counts represent considerable numbers of viable bacteria rather than just debris accumulation (Tables 1 and 2). There appears to be a slight increase in viable bacteria in batch cultures containing Paramecium after the population of grazing ciliates has declined (Table 1). This regrowth of bacteria may be due to release of carbon substrates by the lysing of protozoan cells combined with a reduction in grazing pressure. In the batch cultures containing the entire food chain, carbon recycling evidently led to a significant regrowth of bacteria after Paramecium were eliminated (Fig. 9 and Table 2).

The occurrence of persistent high levels of bacteria in cultures subject to intense grazing by ciliate predators has drawn considerable attention $[14,19$, 34-36] and has led to new mathematical formulations to account for it $[3,18]$. Habte and Alexander [14] showed that Tetrahymena pyriformis failed to consume all bacteria in liquid culture and ceased to take up bacteria when levels fell to $10^{5}-10^{7}$ viable cells $/ \mathrm{ml}$. Watson et al. [36] confirmed these observations on Tetrahymena and noted that when the feeding rate fell to immeasurably low values, the ciliates tended to swim faster than actively feeding ciliates. These "nonfeeding" ciliates remained viable after $55 \mathrm{~h}$. Two basic proposals have been suggested to account for the persistent levels of bacteria in cultures subject to ciliate grazing. van den Ende [35] proposed that bacteria growing on the vessel walls, where they were presumably free of predation, could produce a slough of bacterial cells that would maintain levels in the medium. Bonomi and Fredrickson [3] examined a mathematical formulation that would add the effects of wall growth to a basic Monod model. Jost et al. [18], however, proposcd a generalized Monod model, which he called a multiple saturation model, to include changes in ciliate grazing at low prey density. This multiple saturation model changes equations 5 and 6 to the form 
Table 4. Optimized growth parameters for Multiple Saturation model with biovolume decay constants.

\begin{aligned} & \hline Enterobacter aerogenes-Paramecium primaurelia \\ & \hline$\eta_{\max }=0.0986 \mathrm{~h}^{-1}\left(2.37 \mathrm{da}^{-1}\right) \\ & \mathrm{W}=0.965 \mu \mathrm{m}^{3} / \mathrm{ml} / / \mu \mathrm{m}^{3} / \mathrm{ml} \\ & \mathrm{K}_{\mathrm{i}}=1.108 \times 10^{6} \mu \mathrm{m}^{3} / \mathrm{ml} \\ & \mathrm{K}_{\mathrm{ii}}=0.344 \times 10^{6} \mu \mathrm{m}^{3} / \mathrm{ml} \\ & \mathbf{d}_{\mathrm{g}}=0.0089 \mathrm{~h}^{-1}\left(0.214 \mathrm{da}^{-1}\right) \\ & \mathrm{T}_{\mathrm{g}}$ (doubling time) $=\ln 2 / \eta_{\max }=7.03 \mathrm{~h} \\ &$\hline\end{aligned}

$$
\begin{aligned}
\frac{\mathrm{dB}}{\mathrm{dt}} & =\mu_{\max } \frac{\mathrm{S}}{\mathrm{K}_{\mathrm{s}}+\mathrm{S}} \mathrm{B}-\mathrm{d}_{\mathrm{b}} \mathrm{B}-\frac{\eta_{\max }}{\mathrm{W}} \frac{\mathrm{B}^{2}}{\left(\mathrm{~K}_{\mathrm{i}}+\mathrm{B}\right)\left(\mathrm{K}_{\mathrm{ii}}+\mathrm{B}\right)} \mathrm{G} \\
\frac{\mathrm{dG}}{\mathrm{dt}} & =\eta_{\max } \frac{\mathrm{B}^{2}}{\left(\mathrm{~K}_{\mathrm{i}}+\mathrm{B}\right)\left(\mathrm{K}_{\mathrm{ii}}+\overline{\mathrm{B}}\right)} \mathrm{G}-\mathrm{d}_{\mathrm{g}} \mathrm{G}-\frac{\sigma_{\max }}{\mathrm{Z}} \frac{\mathrm{G}}{\mathrm{K}_{\mathrm{g}}+\mathrm{G}} \mathrm{P}
\end{aligned}
$$

The multiple saturation model contains two saturation constants $-\mathrm{K}_{\mathrm{i}}$ and $\mathrm{K}_{\mathrm{i}}$; together these give a rough measure of threshold prey density. The multiple saturation model replaces the hyperbolic growth response (equation 2) with a sigmoidal response. The multiple saturation model fit data from a Tetrahymena-Azotobacter system better than the Monod model [18].

Because grazing ciliates appear to change their feeding behavior $[14,36]$, the multiple saturation model was examined with the data for the ParameciumEnterobacter system. Optimal parameter values were determined by a nonlinear regression program (Table 4). Values of the maximum specific growth rate $\left(\eta_{\max }\right)$, yield constant $(\mathrm{W})$ and biovolume decay constant $\left(\mathrm{d}_{\mathrm{g}}\right)$, are essentially as in Table 3. The two saturation constants, however, are substantially smaller than $\mathrm{K}_{\mathrm{b}}$. The Monod model predicted levels of bacteria less than $10^{-4} \mu \mathrm{m}^{3} / \mathrm{ml}$, but the multiple saturation model indicates a level of about $1.7 \times 10^{2} \mu \mathrm{m}^{3} / \mathrm{ml}$. Although this predicted level is still less than the observed level of about $1 \times$ $10^{5} \mu \mathrm{m}^{3} / \mathrm{ml}$, the multiple saturation model is much closer than the Monod model.

In the present study, the Monod model with biovolume decay constants appears to be appropriate for the organic carbon substrates-bacteria system and the Paramecium-Didinium system, particularly since Didinium can eliminate all of its prey. The multiple saturation model [18] appears to be more appropriate for the Enterobacter-Paramecium system, especially since it can partially account for persistent levels of bacteria in batch cultures. Possibly both bacterial wall growth and changes in ciliate grazing behavior are involved in determining the final steady levels of bacteria in batch culture. Continuous culture studies would help decide which model is appropriate for each trophic level. The techniques developed in this study and the mathematical models can be applied to the testing of theories on predator-prey systems in continuous culture and suggest the possibility of studying more complex systems involving competition as well as predation.

Acknowledgments. This work, part of a Ph.D. thesis by James Graham, was supported by the Department of Civil Engineering of the University of Michigan. Funds were provided by the United 
States Department of the Interior, Office of Water Resources and Technology, under grant number B-047-MICH, and the National Science Foundation under project number DEB 77-25570. The authors express their appreciation to Caroline Rushford for her help with the experimental phases of this paper.

\section{References}

1. Allen SL, Nerad TA. (1978) Method for the simultaneous establishment of many axenic cultures of Paramecium. J Protozool 25:134-139

2. Bader FG, Tsuchiya HM, Fredrickson AG (1976) Grazing of ciliates on blue-green algae: Effect of ciliate encystment and related phenomena. Biotech Bioeng 18:311-332

3. Bonomi A, Fredrickson AG (1976) Protozoan feeding and bacterial wall growth. Biotech Bioeng 18:239-252

4. Bruns PJ (1973) Cell density as a selective parameter in Tetrahymena. Exptl Cell Res 79: $120-126$

5. Canale RP (1970) An analysis of models describing predator-prey interaction. Biotech Bioeng 12:353-378

6. Canale RP, Lustig TD, Kehrberger PM, Salo JE (1973) Experimental and mathematical modeling studies of protozoan predation on bacteria. Biotech Bioeng 15:707-728

7. Canale RP, Cheng FY (1974) Oxygen utilization in bacterial-protozoan community. J Envir Eng Div ASCE 100:171-185

8. Cook JR (1961) Euglena gracilis in synchronous division. 1. Dry mass and volume characteristics. Plant and Cell Physiol 2:199-202

9. Curds CR, Cockburn A (1971) Continuous monoxenic culture of Tetrahymena pyriformis. J Gen Microbiol 66:95-108

10. Drake JF, Jost JL, Fredrickson AG, Tsuchiya HM (1968) The food chain. In: Saunders JF (ed) Bioregenerative systems. NASA Sp-165, Washington, D.C., pp 87-95

11. Drake JF, Tsuchiya HM (1973) Differential counting in mixed cultures with Coulter counters. Appl Microbiol 26:9-13

12. Fredrickson AG (1977) Behavior of mixed cultures of microorganisms. Ann Rev Microbiol 31:63-87

13. Gause GF (1971) The struggle for existence. The Williams and Wilkins Co. Dover Edition, New York

14. Habte M, Alexander M (1978) Protozoan density and the coexistence of protozoan predators and bacterial prey. Ecology 59:140-146

15. Hamilton RD, Preslan JE (1970) Observations on the continuous culture of a planktonic phagotrophic protozoan. J Exp Marine Biol and Ecol 5:94-104

16. Herbert D, Elsworth R, Telling RC (1956) The continuous culture of bacteria: A theoretical and experimental study. J Gen Microbiol 14:601-622

17. Hewett SW (1980) The effect of prey size on the functional and numerical responses of a protozoan predator to its prey. Ecology 61:1075-1081

18. Jost JL, Drake JF, Tsuchiya HM, Fredrickson AG (1973) Microbial food chains and food webs. J Theor Biol 41:461-484

19. Jost JL, Drake JF, Fredrickson AG, Tsuchiya HM (1973) Interactions of Tetrahymena pyriformis, Escherichia coli, Azotobacter vinelandii, and glucose in a minimal medium. J Bacteriol 113:834-840

20. Kent EB (1981) Life history responses to resource variation in a sessile predator, the ciliate protozoan Tokophrya lemnarum Stein. Ecology 62:296-302

21. Luckinbill LS (1973) Coexistence in laboratory populations of Paramecium aurelia and its predator Didinium nasutum. Ecology 54:1320-1328

22. Luckinbill LS (1974) The effects of space and enrichment on a predator-prey system. Ecology 55:1142-1 147

23. Luckinbill LS (1979) Regulation, stability, and diversity in a model experimental microcosm. Ecology 60:1098-1102 
24. Luckinbill LS (1979) Selection and the $r / K$ continuum in experimental populations of protozoa. Amer Nat 119:427-437

25. Maly EJ (1978) Stability of interaction between Didinium and Paramecium: Effects of dispersal and predator time lag. Ecology 59:733-741

26. May RM (1973) Stability and complexity in model ecosystems. Monographs in Population Biology 6. Princeton University Press, Princeton

27. Monod J (1942) Recherches sur la croissance des cultures bacteriennes. Herman \& Cie, Paris

28. Monod J (1949) The growth of bacterial cultures. Ann Rev Microbiol 3:371-394

29. Proper G, Garver JC (1966) Mass culture of the protozoan Colpoda sieini. Biotech Bioeng 8: 287-296

30. Salt GW (1974) Predator and prey densities as controls of the rate of capture by the predator Didinium nasutum. Ecology 55:434-439

31. Taylor WD, Berger J (1976) Growth of Colpidium campylum in monoenic batch culture. Can Jour Zool 54:392-398

32. Taylor WD, Gates MA, Berger I (1976) Morphological changes during the growth cycle of axenic and monoxenic Tetrahymena pyriformis. Can Jour Zool 54:2011-2018

33. Tsuchiya HM, Drake JF, Jost JL, Fredrickson AG (1972) Predator-prey interactions of Dictyostelium discoideum and Escherichia coli in continuous culture. J Bacteriol 110:1147-1153

34. Tsuchiya HM, Jost JL, Fredrickson AG (1972) Intermicrobial symbiosis. Proc IV IFS: Ferment Tech Today 43-49

35. van den Ende $P$ (1973) Predator-prey interactions in continuous culture. Science 181:562-564

36. Watson PJ, Ohtaguchi K, Fredrickson AG (1981) Kinetics of growth of the ciliate Tetrahymena pyriformis on Escherichia coli. J Gen Microbiol 122:323-333

37. Williams, FM (1971) Dynamics of microbial populations. In: Patten BC (ed) Systems analysis and simulation in ecology. vol. 1, Academic Press, New York, pp 198-267 